\title{
Childhood recurrent abdominal pain and Helicobacter pylori infection, Islamic Republic of Iran
}

\author{
H. Alimohammadi, N. Fouladi, ${ }^{2}$ F. Salehzadeh, ${ }^{3}$ S.A. Alipour ${ }^{4}$ and M.S. Javadi ${ }^{5}$
}

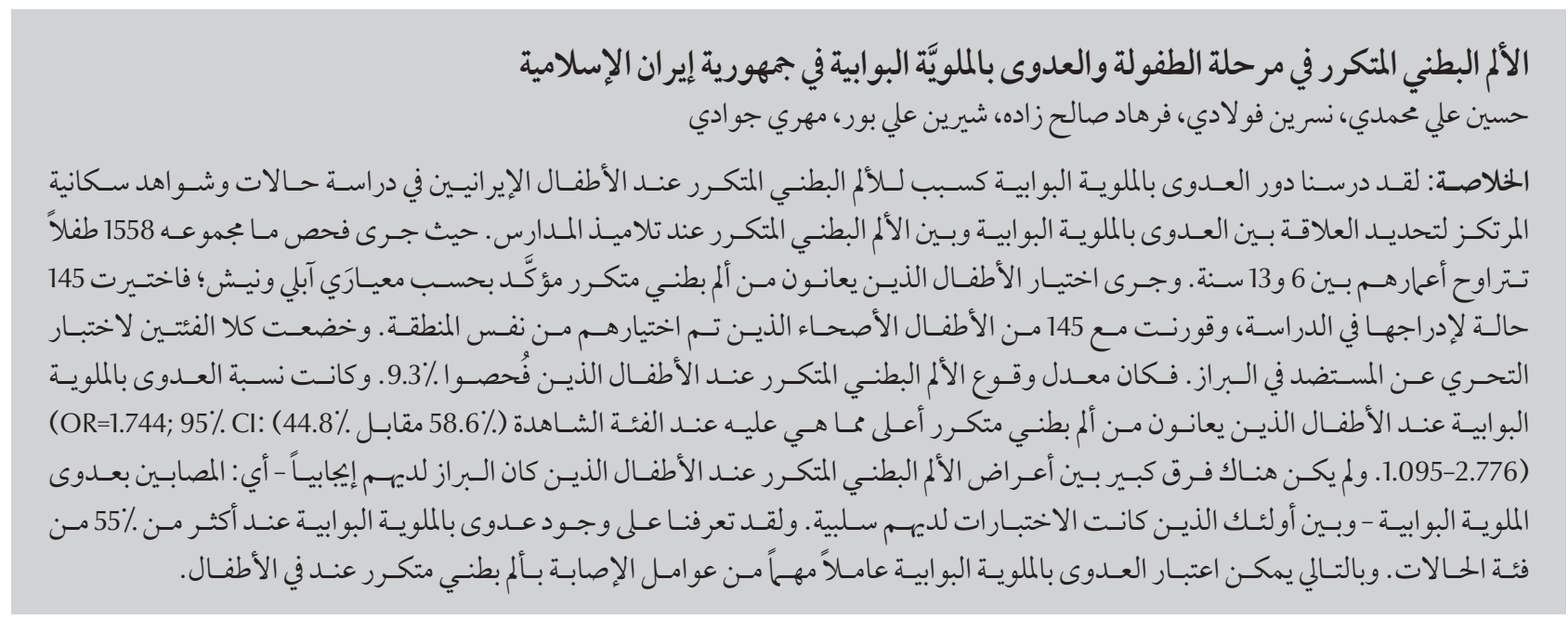

ABSTRACT We examined the role of Helicobacter pylori infection as a cause of recurrent abdominal pain (RAP) among Iranian children in a population-based case-control study to determine the association between $H$. pylori infection and RAP among schoolchildren. A total of 1558 children aged 6-13 years were examined. Children with RAP confirmed by the Apley and Naish criteria were selected; 145 cases were selected for inclusion and were compared with 145 healthy children recruited from the same area. Both groups underwent stool antigen testing. The prevalence of RAP in the children tested was 9.3\%. Children with RAP had a higher H. pylori infection rate than the control group (58.6\% vs 44.8\%) (OR =1.744; 95\% Cl: 1.095-2.776). There was no significant difference between the RAP symptoms in children with positive stool test, i.e. infected with $H$. pylori, and those whose tests were negative. We identified $H$. pylori infection in more than $55 \%$ of the case group. Therefore, $H$. pylori infection can be considered an important factor for RAP in children.

\section{Douleur abdominale récurrente chez l'enfant et infection par Helicobacter pylori, République islamique} d'Iran

RÉSUMÉ Nous avons examiné le rôle de l'infection par Helicobacter pylori en tant que cause de douleur abdominale récurrente parmi des enfants iraniens au cours d'une étude cas-témoin populationnelle afin de déterminer l'association entre cette infection et la douleur abdominale récurrente chez les enfants scolarisés. Au total, 1558 enfants âgés de 6 à 13 ans ont été examinés. Des enfants souffrant d'une douleur abdominale récurrente confirmée selon les critères définis par Apley et Naish ont été sélectionnés : 145 cas répondant au critère d'inclusion ont été comparés avec 145 enfants en bonne santé de la même région. Les deux groupes ont été soumis à un test de recherche d'antigènes dans les selles. L'incidence de la douleur abdominale récurrente testée était de 9,3\%. Les enfants ayant une douleur abdominale récurrente présentaient un taux d'infection par H. pylori plus élevé que le groupe témoin ( $58,6 \%$ contre 44,8 \%; OR=1,744 et IC à $95 \%: 1,095-2,776)$. II n'y avait pas de différence significative entre les symptômes de douleur abdominale récurrente chez les enfants ayant des coprocultures positives, donc une infection par $\mathrm{H}$. pylori, et ceux dont les tests étaient négatifs. Nous avons identifié une infection par H. pylori chez plus de 55 \% d'enfants du groupe témoin. Par conséquent, l'infection par H. pylori peut être considérée comme un facteur important de douleur abdominale chez l'enfant.

${ }^{7}$ Department of Basic Sciences; ${ }^{2}$ Department of Community Medicine; ${ }^{3}$ Department of Paediatrics; ${ }^{4}$ Faculty of Medicine; ${ }^{5}$ Faculty of Nursing, Ardabil University of Medical Sciences, Ardabil, Islamic Republic of Iran (Correspondence to: N. Fouladi: n.fouladi@arums.ac.ir).

Received: 30/08/14; accepted: 27/07/16 


\section{Introduction}

Recurrent abdominal pain (RAP) is a prevalent gastrointestinal problem among preschool children and schoolchildren (1). It is defined as sudden abdominal pain that occurs in the child at least 3 times over a span of 3 months or more, and is severe enough to affect his/her daily activity $(2,3)$. Around $10-15 \%$ of schoolchildren experience RAP, and most often the pain does not interfere with their school attendance, their efficiency, their interaction with other students, their activities while exercising or their personal and family affairs. Children who have RAP are usually at risk of anxiety, depression and loss of self-esteem (4-6). The difference in etiology of RAP in children can arise from functional gastrointestinal disorders or organic diseases (7).

Helicobacter pylori infection commonly occurs in childhood and lasts for a number of years $(1,4,5,8)$. There is some evidence of a positive association between $H$. pylori infection and RAP. Several studies have demonstrated that between a quarter and a third of children with RAP had positive H. pylori infection (9-11). However, other studies did not support a causal association $(6,12,13)$.

The association between $H$. pylori colonization and RAP is still controversial. Therefore, further studies need to be conducted to examine whether the role of H. pylori is causal. Considering the regional conditions and the high incidence of $H$. pylori colonization in the population under study (14), the present study aimed to explore the association between H. pylori infection and RAP in children in Ardabil, in the north west of the Islamic Republic of Iran.

\section{Methods}

\section{Study design and population}

We conducted a population-based, case-control study to investigate the relationship between $H$. pylori infection and RAP in children in Ardabil.

In the first phase of the study, because there is a wide variation in the socioeconomic conditions of the population in different areas of the city, the city was classified into 4 zones, north, south, east and west, and 4 schools were randomly selected in each zone. In each school, based on student numbers, 90-100 students were randomly chosen and examined according to Apley and Naish criteria (3).

Of 1556 students in the 16 schools surveyed from November 2012 to July 2013 in Ardabil city, we identified 155 children with confirmed RAP (all patients were assessed by a consultant paediatrician) (3).

Children who had received antibiotics, acid suppression drugs or anti-H. pylori therapy during the 3 months prior to the study, were excluded from the H. pylori subanalysis. A total of 10 children had received these treatments and were excluded; so the total number of children in the study group was 145 .

In the second phase of the study, 145 healthy children from the same area who had no clinical manifestations of RAP, who met the exclusion criteria and were normal on physical examination were recruited as the control group. The controls were selected to match in terms of age and residential status with the case group. Both groups underwent stool antigen tests using the HpSA enzyme-linked immunosorbent assay.

The study was approved by the ethics board of Ardabil University of
Medical Sciences. Informed consent was obtained from the parents of each child.

\section{Helicobacter pylori stool antigen test}

A microwell-based enzyme immunoassay was used to detect $H$. pylori antigens in stools (FemtoLab H. pylori; Astra, Italy). The stool samples were collected from each participant in clean containers and analysed according to the manufacturer's instructions. Spectrophotometric determination was performed using an enzyme immunoassay microplate reader at wavelength $450 \mathrm{~nm}$ (Stat Fax 2002, USA). Specimens with absorbance values $\geq 0.4$ were defined as positive.

\section{Statistical analysis}

The results were analysed using SPSS, version 16, using chi-squared, Fisher exact test and the $t$-test to examine the relationship between $H$. pylori infection and RAP. Statistical significance was set at the 5\% level.

\section{Results}

We examined 1556 children from 16 schools, and 145 were observed to have RAP, 71 (49\%) boys and 74 (51\%) girls. The prevalence of childhood RAP in our sample was $9.3 \%$.

The stool antigen test for H. pylori was positive for 85 individuals in the case group (58.6\%) and 65 individuals in the control group (44.8\%). The relationship between RAP and H. pylori infection was statistically significant $(\mathrm{OR}=1.744 ;$ 95\% CI: 1.095-2.776, P $=0.01$ ).

The age and sex distribution of the children in the 2 groups was comparable (Table 1). The average age was 8.77 [standard deviation (SD) 1.85] years in the case group and 8.81 (SD $1.90)$ years in the control group. There 


\begin{tabular}{|c|c|c|c|c|c|}
\hline \multirow[t]{2}{*}{ Characteristic } & \multicolumn{2}{|c|}{ Children with RAP } & \multicolumn{2}{|c|}{ Controls } & \multirow[t]{2}{*}{$P$-value } \\
\hline & H. pylori positive & H. pylori negative & H. pylori positive & H. pylori negative & \\
\hline \multirow[t]{2}{*}{ Age (years) mean (SD) } & $8.70(1.80)$ & $8.83(1.94)$ & $8.98(1.91)$ & $8.67(1.88)$ & \multirow[t]{2}{*}{0.8} \\
\hline & No. (\%) & No. (\%) & No. (\%) & No. (\%) & \\
\hline Stool antigen test & $85(58.6)$ & $60(41.4)$ & $65(44.8)$ & $80(55.2)$ & 0.01 \\
\hline \multicolumn{6}{|l|}{ Age (years) } \\
\hline $6-7$ & $28(62.2)$ & $17(37.8)$ & $21(45.7)$ & $25(54.3)$ & \multirow{4}{*}{0.9} \\
\hline $8-9$ & $25(58.1)$ & $18(41.9)$ & $14(34.1)$ & $27(65.9)$ & \\
\hline 10-11 & $28(59.6)$ & $19(40.4)$ & $24(53.3)$ & $21(46.7)$ & \\
\hline $12-13$ & $4(40)$ & $6(60)$ & $6(46.2)$ & $7(53.8)$ & \\
\hline \multicolumn{6}{|l|}{ Sex } \\
\hline Male & $49(69.0)$ & $22(31.0)$ & $36(52.2)$ & $33(47.8)$ & \multirow{2}{*}{0.8} \\
\hline Female & $36(48.6)$ & $38(51.4)$ & $29(38.2)$ & $47(61.8)$ & \\
\hline \multicolumn{6}{|l|}{ Source of drinking water } \\
\hline Mineral water & $9(75.0)$ & $3(25.0)$ & $8(44.4)$ & $10(55.6)$ & \multirow{3}{*}{0.6} \\
\hline Municipal tap water & $63(58.3)$ & 45 (41.7) & $40(47.1)$ & $45(52.9)$ & \\
\hline Boiled water & $13(52)$ & $12(48)$ & $17(40.5)$ & $25(59.9)$ & \\
\hline \multicolumn{6}{|l|}{ Socioeconomic status ${ }^{*}$} \\
\hline Under poverty line & $37(71.2)$ & $15(28.8)$ & $34(55.7)$ & $27(44.3)$ & \multirow{2}{*}{0.02} \\
\hline Above poverty line & $48(51.6)$ & $45(48.4)$ & 31 (36.9) & $53(63.1)$ & \\
\hline
\end{tabular}

${ }^{*}$ Self reported (monthly income verfied with parents then classified in accordance with official poverty line by researcher)

was no statistically significant difference between these groups in terms of age $(P$ $\geq 0.05$ ).

The relationship observed between the rate of $H$. pylori infection and socioeconomic status was statistically significant, with a greater proportion of children from poorer families being infected ( $P=0.02$; CI: 1.29-3.4) (Table $1)$. There was no statistically significant correlation between the rate of $H$. pylori infection and source of drinking water $(P=0.6)$.

The characteristics of RAP in children are shown in Table 2. Duration of abdominal pain was 3-6 months in 101 children (69.65\%) had. In 55 cases, the pain was periumbilical.

In 30 cases (20.7\%) had abdominal pain within 30-60 min following the consumption of milk, yoghurt or ice cream. Defecation reduced pain in 109 (75.2\%) children with RAP.

Over $75 \%$ of children had visited a paediatrician for RAP, and over $95 \%$ reported that the pain inhibited and interfered with their daily activities ( $\mathrm{Ta}$ ble 2).

The main concomitant gastrointestinal symptoms in children were constipation in 25 children (17.24\%), and pain as a result of hunger in 53 children (36.5\%). In these cases also the pain subsided with defecation.

The pain occurring as a result of hunger is one of the commonest symptoms in children, thus, it should be noted that the majority of cases in this study presented with other symptoms along with abdominal pain.

\section{Discussion}

Recurrent abdominal pain is the clinical manifestation of a series of disorders. Abdominal pain is the main gastrointestinal complaint in preschool and school children with a prevalence of about $10 \%$ (1). In the present study, the prevalence of RAP in children was 9.3\%; in some previous studies this ranged from $10 \%$ to $15 \%$ among 4-16-year-old children $(6,14)$. Also, Yang et al. demonstrated a prevalence of $9.8 \%$ in schoolchildren (1), which is in concordance with our findings. The mean age of children suffering from RAP in the present study was 8.7 years, whereas in several previous Iranian studies on RAP in children, carried out in other areas of the country, a mean age of 12.7 years was reported $(5,15))$. Similarly, in a study performed by Ukarapol et al., mean age was 10.5 years for children with RAP (16).

No statistically significant difference was observed between the seianxes in terms of RAP incidence. These findings are in line with studies conducted on Iran, European and Sri Lankan children $(5,6,17,18)$. To date, in almost all studies conducted on children with RAP, around half were male and half female.

In this study, a positive relationship between $H$. pylori infection and RAP was observed, which is in agreement with the findings of Wewer et al. (9), Özen et al. (10) and Das et al. (11). 
Malaty et al. have shown that $H$. $p y$ lori infection occurs in about $81 \%$ of children suffering from RAP (14). The infection mainly develops during childhood and varies across populations.

We found a higher prevalence of $H$. pylori infection in males compared with female children, i.e. male gender is associated with a statistically higher risk of being infected. However, Ertem et al. (19), Iranikhah et al. (20) and Bode et al. (6) found no statistically significant relationship between sex and $H$. pylori infection. Our findings also diverge from the results of Özen et al. (10). The inconsistency among these finding could be ascribed to geographical variation and differences in sample size.

The present study revealed that there was no statistically significant relationship between different age groups with positive stool antigen, while studies carried out by Ertem et al. (19) in Turkey and Nakayama et al. (21) in Japan, indicated a significant relationship between age and $H$. pylori infection. Their findings suggested infection rate increased with age; however, a previous Iranian study found no significant relationship between $H$. pylori infection and age (5). In a study in Texas, USA, it was shown that the greater the age, the lower the infection rate (14). The discrepancies could arise from geographical and genetic variation among the individuals under study.

\begin{tabular}{|c|c|}
\hline Characteristic & No. (\%) \\
\hline \multicolumn{2}{|l|}{ Duration of $R A P$} \\
\hline 2 weeks-3 months & $3(2.1)$ \\
\hline $3-6$ months & $101(69.5)$ \\
\hline 6-12 months & $20(13.9)$ \\
\hline$>12$ months & $21(14.5)$ \\
\hline \multicolumn{2}{|l|}{ Frequency of pain } \\
\hline More than 1 attack per week & $109(75.2)$ \\
\hline More than 1 attack per month & $36(24.8)$ \\
\hline \multicolumn{2}{|l|}{ Location of pain } \\
\hline Epigastric & $49(33.8)$ \\
\hline Periumbilical & $55(37.9)$ \\
\hline Infraumbilical & $6(4.2)$ \\
\hline Undefined & $35(24.1)$ \\
\hline \multicolumn{2}{|c|}{ Previous consultation for abdominal pain } \\
\hline Yes & $111(76.6)$ \\
\hline No & $34(23.4)$ \\
\hline \multicolumn{2}{|l|}{ Pain relieved with defecation } \\
\hline Yes & $109(75.1)$ \\
\hline No & $36(24.9)$ \\
\hline \multicolumn{2}{|c|}{ Interferes with normal daily activities } \\
\hline Yes & 139 (95.9) \\
\hline No & $6(4.1)$ \\
\hline \multicolumn{2}{|c|}{ Pain attack 30-60 min after consuming milk or milk products } \\
\hline Yes & $30(20.7)$ \\
\hline No & $115(79.3)$ \\
\hline
\end{tabular}

Funding: This work was supported by the Ardabil University of Medical Sciences, Islamic Republic of Iran.

\section{References}

1. Yang YJ, Sheu BS, Lee SC, Wu JJ. Short-term recurrent abdominal pain related to Helicobacter pylori infection in children. J Gastroenterol Hepatol. 2005 Mar;20(3):395-400.

2. Devanarayana NM, de Silva DG, de Silva HJ. Aetiology of recurrent abdominal pain in a cohort of Sri Lankan children. J Paediatr Child Health. 2008 Apr;44(4):195-200.

3. Apley J, Naish N. Recurrent abdominal pains: a field survey of 1,000 school children. Arch Dis Child. 1958 Apr;33(168):16570 .

4. Faure C, Wieckowska A. Somatic referral of visceral sensations and rectal sensory threshold for pain in children with functional gastrointestinal disorders. J Pediatr. 2007 Jan;150(1):66-71.

5. Mansour-Ghanaei F, Yousefi-Mashhour M, Joukar F, Sedigh M, Bagher-Zadeh AH, Jafarshad R. Prevalence of Helicobacter pylori infection among children in Rasht, Northern Iran. Middle East J Dig Dis. 2009;1:84-88.
6. Bode G, Brenner H, Adler G, Rothenbacher D. Recurrent abdominal pain in children: evidence from a populationbased study that social and familial factors play a major role but not Helicobacter pylori infection. J Psychosom Res. 2003 May;54(5):417-21.

7. El-Matary W, Spray C, Sandhu B. Irritable bowel syndrome: the commonest cause of recurrent abdominal pain in children. Eur J Pediatr. 2004 Oct;163(10):584-8.

8. Asif HM, Usmanghani K, Naveed A, Uzair M, Akhtar Shah P, Akram M, et al. Prevalence of Helicobacter pylori in gastroenterological disorders in Shifa UI Mulk Memorial Hospital Karachi. Pakistan Journal of Medicinal Plants Research 2011;5(16):3823-6

9. Wewer V, Andersen LP, Paerregaard A, Gernow AB, Hart Hansen JP, Matzen P, et al. The prevalence and related symp- 
tomatology of Helicobacter pylori in children with recurrent abdominal pain. Acta paediatr. 1998 Aug;87(8):830-5.

10. Ozen H, Dinler G, Akyon Y, Kocak N, Yuce A, Gurakan F. Helicobacter pylori infection and recurrent abdominal pain in Turkish children. Helicobacter. 2001 Sep;6(3):234-8.

11. Das BK, Kakkar S, Dixit VK, Kumar M, Nath G, Mishra OP. Helicobacter pylori infection and recurrent abdominal pain in children. J Trop Pediatr. 2003 Aug;49(4):250-2.

12. Wewer V, Andersen LP, Paerregaard A, Gernow A, Hansen JP, Matzen P, et al. Treatment of Helicobacter pylori in children with recurrent abdominal pain. Helicobacter. 2001 Sep;6(3):244-8.

13. Macarthur C, Saunders N, Feldman W, Ipp M, Winders-Lee $P$, Roberts $S$, et al. Helicobacter pylori and childhood recurrent abdominal pain: community based case-control study. BMJ. 1999 Sep 25;319(7213):822-3.

14. Malaty HM, Abudayyeh S, Graham DY, Gilger MA, Rabeneck L, O'Malley K. A prospective study for the association of Helicobacter pylori infection to a multidimensional measure for recurrent abdominal pain in children. Helicobacter. 2006 Aug;11(4):250-7.

15. Masoodpoor N, Darakhshan, Sheikhvatan M. Helicobacter pylori infection in Iranian children with recurrent abdominal pain. Tropical Gastroenterology : official journal of the Digestive Diseases Foundation. 2008 Oct-Dec;29(4):221-3.
16. Ukarapol N, Lertprasertsuk N, Wongsawasdi L. Recurrent abdominal pain in children: the utility of upper endoscopy and histopathology. Singapore Med J. 2004 Mar;45(3):121-4.

17. Masoodpoor N, Darakhshan, Sheikhvatan M. Helicobacter pylori infection in Iranian children with recurrent abdominal pain. Tropical gastroenterology : official journal of the Digestive Diseases Foundation. 2008 Oct-Dec;29(4):221-3.

18. Devanarayana NM, de Silva DG, de Silva HJ. Aetiology of recurrent abdominal pain in a cohort of Sri Lankan children. J Paediatr Child Health. 2008 Apr;44(4):195-200.

19. Ertem D, Harmanci H, Pehlivanoglu E. Helicobacter pylori infection in Turkish preschool and school children: role of socioeconomic factors and breast feeding. The Turkish journal of pediatrics. 2003 Apr-Jun;45(2):114-22.

20. Iranikhah A, Ghadir MR, Sarkeshikian S, Saneian H, Heiari A, Mahvari M. Stool antigen tests for the detection of Helicobacter pylori in children. Iran J Pediatr. 2013 Apr;23(2):138-42.

21. Nakayama Y, Horiuchi A, Kumagai T, Kubota S, Taki Y, Oishi $\mathrm{S}$, et al. Psychiatric, somatic, and gastrointestinal disorders, and Helicobacter pylori infection in children with recurrent abdominal pain. Archives of disease in childhood. 2006 Aug;91(8):671-4. 